\title{
THE SELECTION ASSESSMENT OF HIBRIDES OF THE FAMILY ULMACEAE MIRB. FOR DECORATIVE GARDENING OF THE LOWER VOLGA REGION
}

\author{
СЕЛЕКЦИОННАЯ ОЦЕНКА ГИБРИДОВ СЕМЕЙСТВА ULMACEAE MIRВ. \\ ДЛЯ ДЕКОРАТИВНОГО САДОВОДСТВА НИЖНЕГО ПОВОЛЖЬЯ
}

\section{Podkovyrov, T. Konotopskay, Candidates of Agricultural Sciences}

И.Ю. Подковыров, Т.М. Конотопская, кандидаты сельскохозяйственных наук

Volgograd State Agrarian University, Volgograd City, Russia

Волгоградский государственный аграрный университет, Волгоград, Россия

Phone: +7 (8442) 41-17-75, E-mail: parmelia@mail.ru

Received November 11, 2012

\begin{abstract}
The article considers the issues of selection of the elm for decorative gardening. On the basis of complex analysis of the estimation of economically valuable selection of samples. Shown the advantage of individual selection. Investigated the variability of morphological characteristics of the form of the crown, of leaves and fruits. Allocated promising group of plants that allows you to continue breeding work. Summarizes the results of the hybridization of species of elm.
\end{abstract}

\section{АННОТАЦИЯ}

В статье рассмотрены вопросы селекиии вяза для декоративного садоводства. На основании комплексного анализа произведена оценка хозяйственно цзенных селекционных образиов. Показано преимущество индивидуального отбора. Изучена изменчивость морфологических признаков формы кроны, листьев и плодов. Выделены перспективные группь растений, что позволяет продолжать селекционную работу. Обобщены результаты гибридизации видов вяза.

\section{KEY WORDS}

Selection of trees; Decorative gardening; Variability of signs; Individual selection; Hybridization; Elm.

КЛЮЧЕВЫЕ СЛОВА

Селекиия деревьев; Декоративное садоводство; Изменчивость признаков; Индивидуальный отбор; Гибридизачия; Вяз.

Резервом повышения устойчивости и эффективности ильмовых пород является расширение их видового состава и использование богатой внутривидовой разнокачественности. Родовой комплекс Ulmus L. является хорошим модельным объектом для изучения вопросов наследования признаков и их изменчивости, гибридизации. Представляют интерес вопросы селекции и семеноводства вяза, размножения селекционно улучшенного материала, районирования видов, гибридов и форм.

В регионе накоплен значительный опыт селекции и семноводства вяза. Отдельные вопросы рассмотрены в трудах Г.П. Озолина, Г.Я. Маттиса, С.Н. Крючкова, Е.А. Крюковой,
Г.П. Архангельской, А.П. Богун [1, 2, 3, 4, 5]. Проведён отбор лучших биотипов, которые поставлены на государственный учёт. На их основе в Нижнем Поволжье созданы и функционируют клоновые и семейственные лесосеменные плантации (ЛСП). Однако их роль недооценена в декоративном садоводстве.

Современные тенденции развития данных отраслей требуют использование в производстве качественного посадочного материала высокой селекционной категории. В сложных природно-климатических условиях Нижнего Поволжья создание долговечных и устойчивых насаждений возможно только с внедрением селекционных достижений в про- 
изводство. Периодически повторяющиеся в регионе экстремально неблагоприятные годы (например, рекордно морозные зимы 1968/69, 1971/72, 2010/11 гг. и последовавшие за ними жестокие засухи 1969, 1972 и 2011 гг.) привели к распаду большинства существующих посадок. Однако на фоне общей гибели деревьев до настоящего времени сохранились отдельные экземпляры, устойчивые к комплексу неблагоприятных факторов. Эти растения могут стать основой для селекции.

\section{МАТЕРИАЛЫ И МЕТОДИКА ИССЛЕДОВАНИЙ}

Экспериментальная часть работы выполнялась в течение 2000-2012 гг., на модельных объектах в трёх природных зонах Нижнего Поволжья - чернозёмной степи, сухой степи и полупустыне. Объектами послужили искусственные и естественные насаждения с участием ильмовых пород, расположенные на различных участках рельефа местности.

Производился отбор кандидатов в плюсовые деревья по общепринятой методике. Отбирались деревья значительно превышающие по таксационным показателям средние значения насаждений и имеющие отличное состояние $[1,2]$. Комплексную оценку производили на основании изучения роста, развития, устойчивости к засухе, засолению, графиозу в вегетационных и грядочных опытах по общепринятым методикам.

Морфологический анализ родительских форм и гибридов проводился на сеянцах, взрослых деревьях и гербарных образцах. Для гербаризации брали побеги из середины кроны с юго-западной стороны. При морфологическом описании листьев и плодов использовали 13 признаков: I - длина черешка, мм, А длина листовой пластинки, мм, В - ширина листовой пластинки, мм, D - расстояние от основания до самой широкой части листовой пластинки, мм, W - верхний угол листа, Н1 и H2 - больший и меньший нижние углы листа, $\mathrm{N}$ - количество боковых жилок, шт., $\mathrm{X}$ - длина крылатки (мм), Y - ширина крылатки (мм), $\mathrm{Z}$ - расстояние от основания до семени (мм). А также следующие соотношения: B/A - листовой коэффициент, D/A, I/A, H2/H1.

Помимо коэффициента вариации для характеристики изменчивости применялся метод главных компонент [6]. Обработка мето- дом главных компонент позволяет выделить для дальнейшего анализа основные компоненты, собственные значения которых больше 1. Весовые коэффициенты при главных компонентах определяют признаки, которые наиболее полно характеризуют изучаемый объект.

\section{РЕЗУЛЬТАТЫ И ИХ ОБСУЖДЕНИЕ}

Виды семейства Ulmaceae Mirb. широко распространены в естественных насаждениях степной и полупустынной зон Нижнего Поволжья. Они входят в состав, как смешанных лиственных лесов, так и образуют чистые насаждения по поймам рек, оврагам и балкам. К аборигенным видам относят вяз гладкий ( $U l$. laevis Pall) и граболистный (Ul. carpinifolia Rup. ex Suchow). Наиболее распространён в регионе интродуцированный вяз приземистый (Ul. pumila L.), который занимает более $70 \%$ площадей всех насаждений.

Исследованиями установлена спонтанная гибридизация между Ul. pumila и Ul. carpinifolia. Предпосылками её появления вилась совместное произрастание видов в насаждениях, лёгкая скрещиваемость в связи с близким систематическим родством, одновременное цветение. Установлено, что образовавшиеся гибриды значительно отличаются от родительских видов и превосходят их по комплексу хозяйственно ценных свойств. Данная группа растений оказалась ценной для селекционной работы и получения сортов. Изучение роста видов и гибридов в насаждениях показало их преимущества по сравнению с вязом приземистым (табл. 1).

Высота гибридов изменяется в зависимости от лесорастительных условий. В лучших условиях произрастания (I группа лесопригодности) они достигают высоты 10,2-10,3 м, а в более худших (III группа лесопригодности) их средняя высота составляет 8,0-8,3 м.

Удалённость гибридов от родительских форм определялась путём кластерного анализа морфометрических признаков, основанного на измерении дистанций между ними. В качестве метрики использовалось Евклидово расстояние. В целом гибриды очень неоднородны. Однако дистанция между ними преимущественно ближе, по сравнению с родительскими видами. Гибриды по какому-либо конкретному признаку могут иметь большее 
сходство то с одним, то с другим видом. Например, к вязу граболистному ближе гибриды с селекционными номерами 25п, 25c и 24a, а к вязу приземистому 24в. Обработка данных морфометрического анализа методом главных компонент позволила установить признаки, характеризующие гибриды вяза (рис. 1).

Таблица 1. - Таксационные показатели гибридов вяза в сухостепной зоне на светло-каштановых почвах разной лесопригодности

\begin{tabular}{|c|c|c|c|c|c|}
\hline Систематическая группа & $\begin{array}{c}\text { Группа } \\
\text { Лесопригодности } \\
\text { почв }\end{array}$ & Возраст, лет & Высота, м & Диаметр, см & Состояние, балл \\
\hline \multirow{3}{*}{$\begin{array}{l}\text { Ul. pumila } x \\
\text { carpinifolia }\end{array}$} & I & 40 & 10,3 & 21,7 & 5,0 \\
\hline & II & 40 & 10,0 & 21,0 & 5,0 \\
\hline & III & 40 & 8,0 & 19,0 & 5,0 \\
\hline \multirow{3}{*}{ Ul. carpinifolia $x$ pumila } & I & 40 & 10,2 & 20,2 & 4,6 \\
\hline & II & 40 & 9,8 & 21,0 & 4,5 \\
\hline & III & 40 & 8,3 & 21,2 & 4,3 \\
\hline \multirow{2}{*}{$\begin{array}{l}\text { Ul. pumila } \\
\text { (контроль) }\end{array}$} & I & $40(26)^{*}$ & 6,1 & 15,4 & 2,7 \\
\hline & III & $40(26)^{*}$ & 4,9 & 13,4 & 2,5 \\
\hline
\end{tabular}

Примечание: * В скобках указан возраст порослевого поколения

Таблица 2 - Биометрические показатели плодов видов и гибридов ильмовых

\begin{tabular}{|c|c|c|c|c|c|c|c|}
\hline \multirow[b]{2}{*}{ Систематическая группа } & \multicolumn{3}{|c|}{ Длина крылатки, см } & \multicolumn{3}{|c|}{ Ширина крылатки, см } & \multirow[b]{2}{*}{$\begin{array}{c}\text { Площадь плода, } \\
\text { см² }^{2}\end{array}$} \\
\hline & Min & $\begin{array}{c}\text { Среднее и его } \\
\text { ошибка }\end{array}$ & $\operatorname{Max}$ & Min & $\begin{array}{c}\text { Среднее и его } \\
\text { ошибка }\end{array}$ & Max & \\
\hline Ul. pumila L. & 0,9 & $1,0 \pm 0,04$ & 1,2 & 1,0 & $1,1 \pm 0,04$ & 1,2 & 0,9 \\
\hline Ul. pumila x carpinifolia & 1,2 & $1,4 \pm 0,08$ & 1,5 & 1,1 & $1,3 \pm 0,06$ & 1,4 & 1,5 \\
\hline Ul. carpinifolia x pumila & 1,2 & $1,4 \pm 0,04$ & 1,8 & 1,3 & $1,5 \pm 0,06$ & 1,8 & 1,7 \\
\hline $\begin{array}{l}\text { Ul. carpinifolia Rupp. ex } \\
\text { Suckow }\end{array}$ & 1,2 & $1,5 \pm 0,06$ & 1,7 & 1,0 & $1,3 \pm 0,06$ & 1,5 & 1,5 \\
\hline Ul. laevis Pall. & 1,1 & $1,3 \pm 0,04$ & 1,6 & 0,9 & $1,1 \pm 0,03$ & 1,4 & 1,2 \\
\hline
\end{tabular}

Рассмотрим наследование признаков при межвидовой гибридизации видов рода Ulmus $L$. Анализ проводился на отобранных плюсовых деревьях вяза граболистного их гибридах с вязом приземистым. Наследование признаков изучалось у потомства 50 плюсовых деревьев (30 гибридов вяза приземистого и граболистного и 20 вяза граболистного). Исследования проводились на ЛСП площадью 3 га. Количество изучаемых растений 520. ЛСП состоит из 2-х блоков: гибридов (344 дерева) и вяза граболистного (176 деревьев). Схема смешения в блоках спиральная.

Изучалась встречаемость морфологических признаков, имеющих хозяйственное и научное значение: форма кроны, ствола, листьев и наличие пробковых наростов.

Доминантные признаки дают морфологическую характеристику гибридов, как систематической совокупности. Вместе с тем у гибридов признаки наследуются от родительских форм. Данное потомство является полусибсовым (известны характеристики только материнских деревьев). Установлено, что ма- теринские деревья это гибриды первого поколения, а анализируемое потомство - гибриды, полученные от свободного опыления F1 с такими же гибридами и вязом приземистым. По первому закону Г. Менделя гибриды первого поколения единообразны. Что мы и получили, отбирая плюсовые деревья одинакового фенотипа, превышающие в росте по диаметру и высоте (гетерозисные) в насаждениях вяза приземистого.

У гибридов F2 классическое расщепление по второму закону Г. Менделя $-3: 1$ не наблюдается ни по одной паре признаков. В большинстве случаев наблюдается распределение признаков в пропорции приблизительно 50/50. Такое возможно только в одном случае - когда гетерозигота по определённому признаку скрещивается с рецессивной гомозиготой. Такое распределение получается при наследовании формы крон (с ажурной кроной $48,7 \%$, с плотной $-51,3 \%$ ), формы ствола (с прямым стволом 42,8\%, с кривым - 57,2\%), размера листьев (с мелкими листьями 53,4\%, с крупными - 46,6\%). Остальные признаки не 
подчиняются данному закону наследования, это означает, что они формируются под воздействием нескольких генов.

Очень редко как у вяза граболистного, так и у гибридов встречается пирамидальная форма кроны и равнобокие листья, а также у гибридов пробковые выросты.

У вяза граболистного расщепление по второму закону Г. Менделя произошло по ширине листа (с широкими листьями 74,8\%, с узкими - 25,2\%), по форме вершинки листа (с острой вершинкой 73,1\%, с тупой - 27,9\%), по цвету коры (с тёмной корой $74,2 \%$, со светлой $-25,8 \%$ ).

Вяз гибридный отличается значительной вариабельностью физиологических показате- лей. По свойствам тяготеет к материнскому виду, а иногда превосходит его. Наибольшей засухоустойчивостью обладают гибриды с преобладанием признаков вяза приземистого. При небольшом засолении $(0,1 \%)$ гибриды превосходят родительские виды, но при более сильном засолении $(0,2 \%)$ солеустойчивость их снижается. Морозоустойчивость гибридов значительная (выдерживают температуру почвы до -19,50С), но немного уступают вязу граболистному. Являются восприимчивыми к графиозу. Интегральный показатель гибридов достаточно высокий (3,5 балла), поэтому они очень перспективны для декоративного садоводства (табл. 3).

Таблица 3 - Интегральная оценка видов и гибридов ильмовых по физиологическим показателям

\begin{tabular}{|c|c|c|c|c|c|c|}
\hline \multirow{2}{*}{ Систематическая группа } & \multicolumn{5}{|c|}{ Устойчивость, баллы } & \multirow{2}{*}{ Ранг } \\
\hline & к засухе & к засолению & к морозу & к графиозу & средн. балл & \\
\hline Ul. pumila L. & 3,0 & 3,2 & 0,9 & 4,8 & 3,0 & 4 \\
\hline Ul. pumila x carpinifolia & 3,5 & 3,3 & 3,0 & 4,3 & 3,5 & 1 \\
\hline Ul. carpinifolia Rupp. ex Suckow & 3,8 & 3,5 & 3,0 & 3,4 & 3,4 & 2 \\
\hline Ul. laevis Pall. & 3,0 & 3,9 & нет данных & 3,1 & 3,3 & 3 \\
\hline
\end{tabular}

Среди видов наибольшее разнообразие форм с хозяйственно-ценными признаками отмечается у вяза граболистного, который в условиях Нижнего Поволжья является аборигенным видом. Интродуценты менее разнообразны, поэтому для обогащения генетического, а, следовательно, и морфологического разнообразия необходимы работы по их гибридизации.
Отбор сортообразцов проводился в имеющихся коллекционных фондах на основании оценки растений по хозяйственноценным качествам. Первичные сведения получены на основании анализа базы данных. В дальнейшем они проверялись и уточнялись в полевых условиях. В результате были выделены следующие сортообразцы (табл. 4).

Таблица 4 - Характеристика перспективных сортообразцов

\begin{tabular}{|c|c|c|c|c|}
\hline Систематическая группа & $\begin{array}{c}\text { Декоративные } \\
\text { качества }\end{array}$ & $\begin{array}{c}\text { Возраст, } \\
\text { лет }\end{array}$ & $\begin{array}{c}\text { Высота, } \\
\text { м }\end{array}$ & $\begin{array}{c}\text { Протяжённость } \\
\text { кроны, м }\end{array}$ \\
\hline Ulmus pumila & Пирамидальная крона & 25 & 12 & $2,0 \times 2,0$ \\
\hline Ulmus pumila x carpinifolia & Ажурная крона & 7 & 3,5 & $3,1 \times 3,1$ \\
\hline Ulmus pumila x carpinifolia & Плотная крона & 7 & 3,4 & $3,0 \times 3,0$ \\
\hline Ulmus pumila $x$ carpinifolia & Устойчивый к листоеду & 7 & 3,2 & $2,9 \times 2,8$ \\
\hline Ulmus carpinifolia & $\begin{array}{c}\text { Засухоустойчивая форма } \\
\text { Долговечная в тяжёлых лесораститель- } \\
\text { ных условиях }\end{array}$ & 78 & 7,4 & $5,0 \times 5,1$ \\
\hline
\end{tabular}

Наибольшее количество сортообразцов с интересующими нас признаками обнаружено на коллекционном участке Волгоградского лесхоза среди гибридов вяза. Это подтверждает предположения, что гибриды второго поколения ценны для селекции. Среди видов наибольшее разнообразие форм с хозяйствен- но-ценными признаками отмечается у вяза граболистного.

Среди гибридной группы выделен перспективный сортообразец «Памяти Гельмута Маттиса», отличающийся быстрым ростом и ажурной кроной [7]. 


\section{ВЫВОДЫ}

1. Ильмовые отличаются высокой степенью изменчивости морфологических признаков, что позволяет отбирать декоративные формы с комплексом хозяйственно ценных качеств для выращивания в тяжёлых природно-климатических условиях Нижнего Поволжья.

2. Селекционная оценка межвидовых гибридов показала их перспективность для выращивания на каштановых и бурых почвах.
Гибридные растения превосходят родительские виды на $18-26 \%$ по росту и физиологической устойчивости. Для оценки гибридного поколения применимы компонентный и генетический анализы.

3. В результате отобраны селекционные образцы, отличающиеся декоративностью кроны. Изучение морфологических признаков крон гибридов позволило выявить закономерности их наследования в семенном потомстве.

\section{БИБЛИОГРАФИЯ}

Маттис Г.Я., Крючков С.Н., Мухаев Б.А. Семеноводство древесных пород для степного лесоразведения. - М.: Агропромиздат, 1986. 215 с.

Озолин Г.П., Маттис Г.Я., Калинина И.В. Селекция древесных пород для защитного лесоразведения. М.: Лесная промышленность, 1978. 153 с.

Крюкова Е.А., Плотникова Т.С., Биологические основы защиты дуба и вяза от инфекционного усыхания. М.: Агропромиздат, 1991. $127 \mathrm{c.}$

Богун А.П. Пути повышения устойчивоти вязовых насаждений сухой степи насветло-каштановых почвах Ергеней. Волгоград, 1990. $165 \mathrm{c.}$
Архангельская Г.П. Физиологические механизмы засухоустойчивости вязов // Бюллетень ВНИАЛМИ. Вып. 3(31), Волгоград, 1978. С. 30 - 33.

Андерсон Т. Введение в многомерный статистический анализ. - М.: ГИФМЛ, 1963.500 c.

Авторское свидетельство № 41663. Вяз Памяти Гельмута Маттиса. / Подковыров И.Ю., Крючков С.Н., Попов П.П. Зарегистрировано в Государственном реестре селекционных достижений, допущенных к использованию от 04.10.2005. 